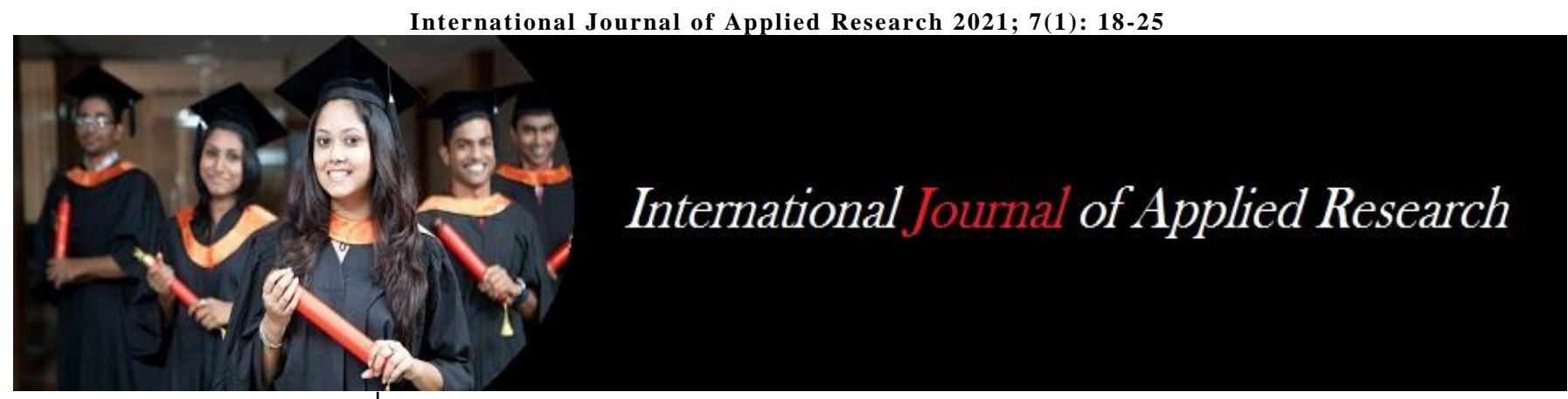

ISSN Print: 2394-7500

ISSN Online: 2394-5869

Impact Factor: 8.4

IJAR 2021; 7(1): 18-25

www.allresearchjournal.com

Received: 13-11-2020

Accepted: 15-12-2020

Chandra Shekhar Sarkar

Research Scholar,

Department of Geography,

Presidency University,

Kolkata, West Bengal, India

Gouri Mondal

Research Scholar,

Department of Education,

University of Calcutta,

Kolkata, West Bengal, India
Corresponding Author: Chandra Shekhar Sarkar Research Scholar,

Department of Geography, Presidency University, Kolkata, West Bengal, India

\section{Women education and gender disparity in Murshidabad district of West Bengal}

\author{
Chandra Shekhar Sarkar and Gouri Mondal
}

DOI: https://doi.org/10.22271/allresearch.2021.v7.i1a.8141

\section{Abstract}

Education is a crucial social factor that helps in development by expending knowledge, thought, ability and skill. However, in our patriarchal society, the educational status of women is far behind than men. The present study is an attempt to analyses the educational status of women and male-female disparity in education in the Murshidabad district of West Bengal using the secondary data from the Census of India and the district statistical handbook and male-female disparity in literacy is calculated based on Sopher's Disparity Index method. The result of the study indicates that the Murshidabad district is backward compared to other districts in West Bengal. The present female-literacy rate of the district is $67.53 \%$, which is below the state average (77\%) and the overall district rank is 16th in 2011 out of 19 districts. Still, the female literacy rate of the district is increased by $13.18 \%$ over the past decade. The study reveals that there is an uneven distribution of block-level female literacy rate in Murshidabad district in both the Census year 2001 and 2011, as well as it is also noticed that female literacy rate is very high in middle and southern blocks such as Berhampore, Hariharpara and Beldanga I and very low in the northern blocks namely Farakka, Suti I, Suti II and Samserganj block. The male-female disparity in literacy is very high in western blocks like Kandi (0.147), Nabagram (0.141), Khargram (0.140) and Burwan (.0136) and very low in the eastern blocks viz. Bhagwangola II (.039), Domkal (.052). However, the overall district-level female literacy rate is gradually increasing and gender disparity in education is decreasing, the Government should take appropriate measures to accelerate women education and eradicate male-female inequality in education.

Keywords: Education, female literacy, literacy change, male-female disparity

\section{Introduction}

Education can change in mind, thought, outlook, personality and leads enlightenment as it facilitates knowledge, skills and abilities, which helps to achieve encouraging attitudes. Education makes a man civilized and takes a responsible role in making humans as social. Consequently, education is considered one of the basics need after food clothing and shelter (Vasantha, 2017). It is one of the crucial elements to the progress of an individual, social group, or a community, in particular, women's status in society. Women education denotes every section of education that aims at improving the knowledge, capability, thought and skills of women and girls. Educated women can bring their socio-economic changes. Swami Vivekananda said, "There is no chance for the welfare of the world unless the condition of women is improved." Female literacy has been improving over the years in India (Margaret, $2017)^{[15]}$. The female literacy rate in our country has increased by 11.5 percent over the last decade from 54 percent in 2001 to 65.5 percent in 2011 . The constitution of India not only provides for equal rights for women and men but also for making special arrangements for women. After independence different five-year plans have successively placed for the betterment of women, which particular emphasis on providing minimum health facilities and nutrition for women and children, acceleration of women's education, their increase in the welfare service for women in need (Ghosh, 2017). Nevertheless, the condition of women has not improved and they are lagged behind men. In this regard, researchers have been selected to study the educational status of women and gender inequality. Significant research work on women education has been carried out by various scholars like Santu Biswas (Biswas, 2017), Vasantha Gouri (Gouri, 2017) ${ }^{[6]}$, Kalpana Saxena (Sexena, 2017) ${ }^{[20]}$, Dr. Prameela Margaret 
(Margaret, 2017) ${ }^{[15]}$, Dr. Pratap Kumar Jana (Jana, 2018), Parikshit Chakraborty (Chakraborty, 2019) ${ }^{[4]}$ and Indrakshi Ghosh (Ghosh, 2019) ${ }^{[5]}$. Important research work on gender disparity in education also carried out by various scholars such as A. A. Mulimani and L. M. Pujar (2015) ${ }^{[13]}$, Laura D. Smith (Smith, 2015), Roy and Anushri Mondal (2015) ${ }^{[17]}$, Narender Kumar, Naresh Kumar and Ritu Rani (Kumar, Kumar \& Rani, 2016) ${ }^{[10]}$, Bikash Barman1 and Dr. Pradip Chouhan (Barman \& Chohan, 2017) ${ }^{[2]}$, N. K. Manjunatha and Dr. S. M. Hurakadli (Manjunath \& Hurakadi, 2017) ${ }^{[9]}$, Nitin N. Mundhe, Dhondiram B. Pawar and Priyanka D. Rokade (Mundhe, Pawar \& Rokade, 2017) ${ }^{[14]}$, Krishnendu Maji and Dr. Sumana Sarkar (Maji \& Sarkar, 2018) ${ }^{[12]}$, Mahafujur Rahaman and Hasibur Rahaman (Rahaman \& Rahaman, 2018) ${ }^{[16]}$, Debasish Najmus Sakib and Dr. Asheesh Srivastava (2019), and Dr. A. N. Patil and Dr. S. A.
Suryawanshi (Pati \& Suryawanshi, 2019) ${ }^{[1]}$. Therefore, the present study tries to analyses the educational status of women and gender disparity in Murshidabad district of West Bengal, because this district is a backward district in terms of female education. Although few research works have been done on women's education in this district, block-wise details research work on women's education and malefemale disparity in education has been not done.

\section{Objectives}

There are three objectives of the study. Firstly, to determine the position of Murshidabad district in West Bengal on female education. Secondly, to study the block-wise female education status of Murshidabad district in 2001 and 2011. Thirdly, to identify the block-wise male-female disparity in the literacy of Murshidabad district.
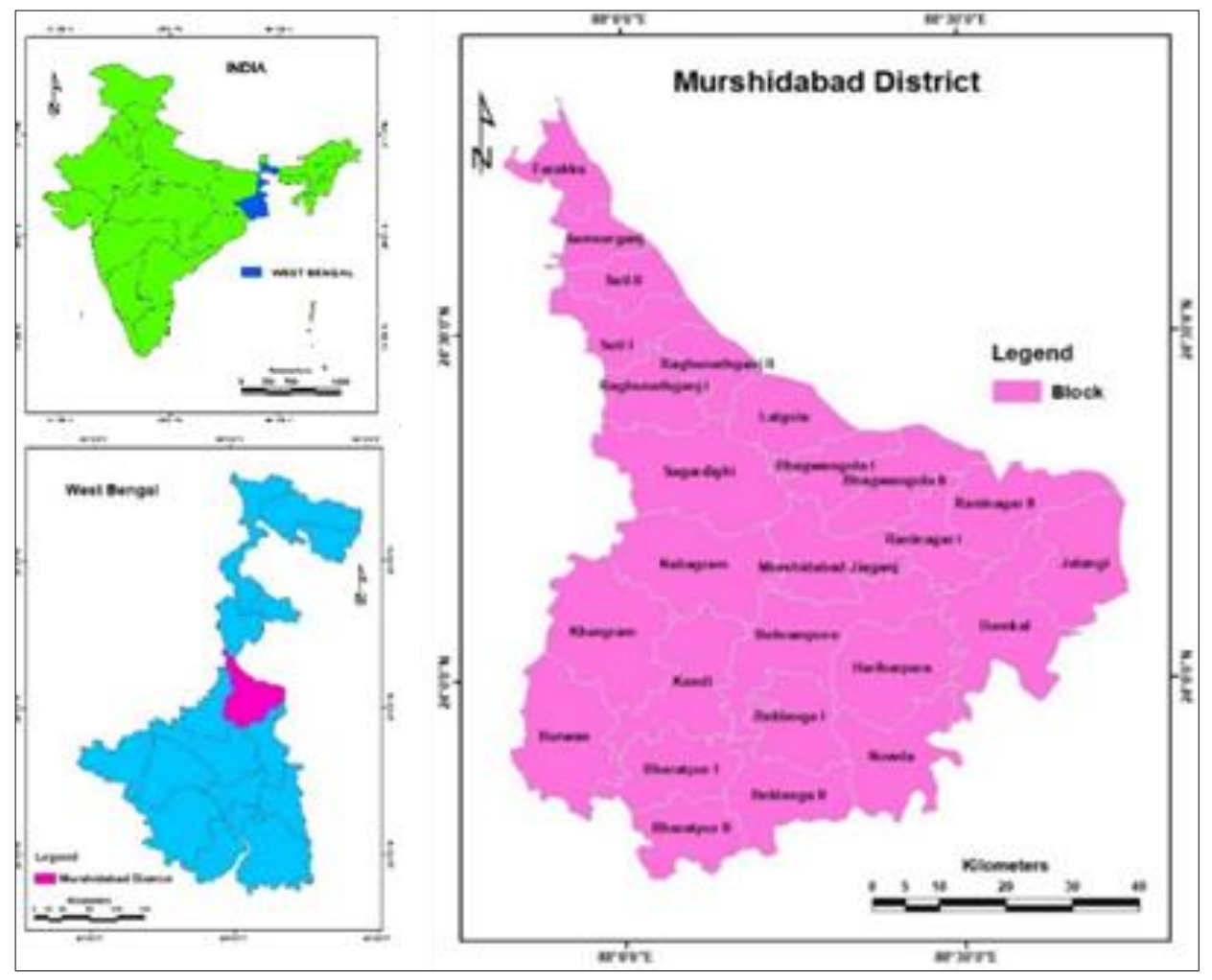

Fig 1: Location map of the study area

\section{Methodology \\ 3.1 Study area}

The study area consists of the Murshidabad district of West Bengal in India. Murshidabad district is the northernmost district of the Presidency Division of West Bengal and situated on the left bank of Ganges river and the latitudinal extension is from $23^{\circ} 43^{\prime} \mathrm{N}$ to $24^{\circ} 52^{\prime} \mathrm{N}$ and longitudinal extension are from $87^{\circ} 49^{\prime} \mathrm{E}$ to $88^{\circ} 44^{\prime} \mathrm{E}$. and the total area is 5341 square kilometres as per the 2011 census. There are a total of 5 subdivisions, 26 blocks, 8 municipalities, 254 gram-panchayats and 1937 villages in the district. The total population of the district is 7103807 and the total male and female population are 3627564 and 3476243, respectively.

\subsection{Calculation method}

The present paper aims to study the female educational status and the male-female disparity in the literacy of the Murshidabad district using the secondary data. The literacy rate has been computed for the population above 6 years. For the calculation of male-female disparity in literacy,
Sopher's Disparity Index (Sopher, 1974) ${ }^{[21]}$ method has been applied. The disparity index formula:

$\mathrm{DI}=\log (\mathrm{X} 2 / \mathrm{X} 1)+\log [(100-\mathrm{X} 1) /(100-\mathrm{X} 2)]$

Where DI is Disparity Index, X2 is considered for the male literacy rate and $\mathrm{X} 1$ is considered for the female literacy rate.

\subsection{Data collection}

This study was conducted through the analysis of secondary data. Secondary data were collected from the Census of India and the Bureau of Applied Economics and Statistics.

\subsection{Data analysis}

To assess the female educational status and gender disparity in education in Murshidabad district, we first prepared statistical tables by using Microsoft excel and then location map and choropleth maps were made by using ArcGIS. 


\section{Result and Discussion}

4.1 District wise female literacy rate in West Bengal and Murshidabad district position in it

According to the Census report of 2011, the female literacy rate in West Bengal is $77.08 \%$, which is almost $12 \%$ higher than the national level $(65.5 \%)$. But literacy rate is unequally distributed in districts. Table-1 shows that the female literacy rate is highest in Purba Medinipur (87.66\%), followed by Kolkata (87.14). It is also very high in North 24 Parganas (84.95\%), Howrah (83.85\%) and Hooghly district $(82.55 \%)$. The female literacy rate is lowest in Uttar Dinajpur district $(60.13 \%)$ and also very poor in Maldah (62.71\%), Purulia (65.38\%) and Murshidabad district (67.53\%). Moderate female literacy is identified in
Darjeeling, Paschim Medinipur, South 24 Parganas, Burdwan, Nadia, Cooch Behar, Jalpaiguri, Bankura and Birbhum district. The literacy rate in the Murshidabad district is comparatively backward in terms of female education. Here the female literacy rate is almost $10 \%$ less than the State level but 2\% higher than our national level. Out of 19 districts, the female literacy rank of the district is 16th. However, the district female literacy rank has declined one step from the last decade. In the Census year 2001, Murshidabad district's female literacy was $54.35 \%$, which was $14.29 \%$ less than the state level and $0.35 \%$ higher than the country level and the district rank was 17th out of 19 districts in West Bengal.

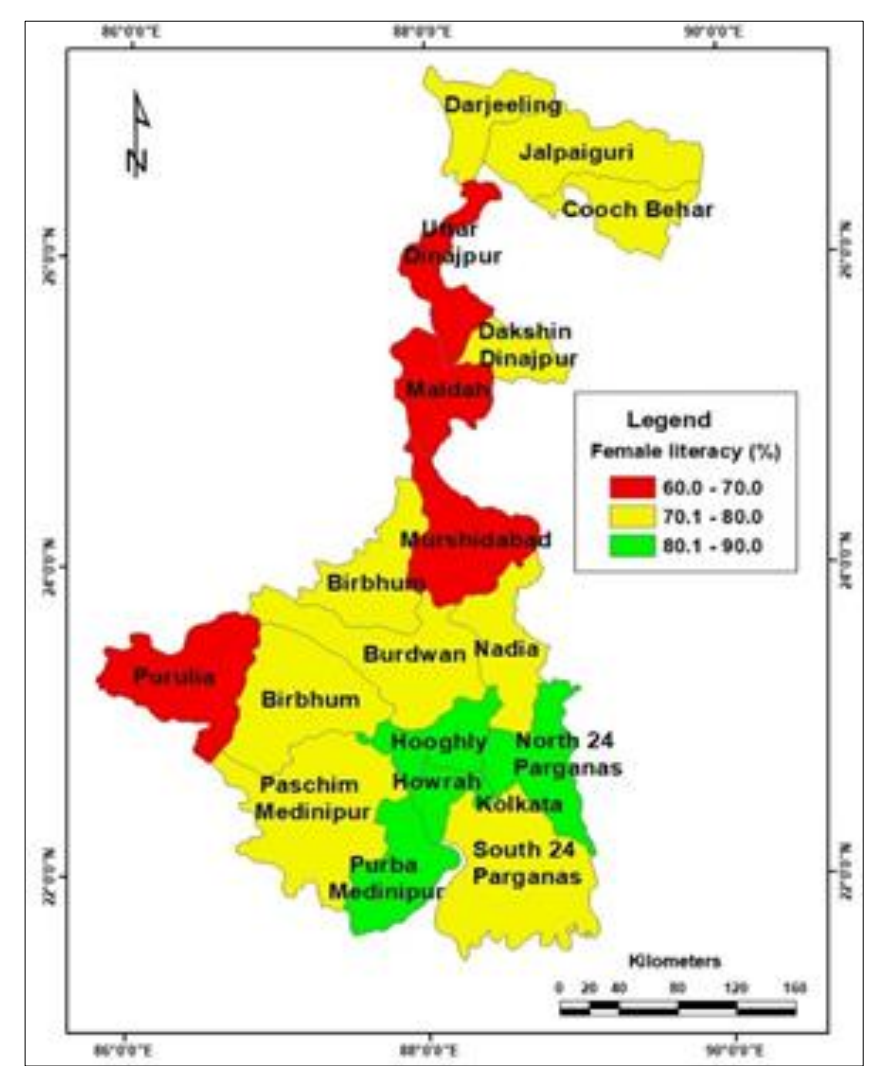

Fig 2: District wise literacy rate in West Bengal - 2011

Table 1: Showing female literacy rate in West Bengal

\begin{tabular}{|c|c|c|c|c|}
\hline District Name & Female literacy 2001 (\%) & Rank & Female literacy 2011 (\%) & Rank \\
\hline Purba Medinipur & 80.16 & 2 & 87.66 & 1 \\
\hline Kolkata & 80.86 & 1 & 87.14 & 2 \\
\hline North 24 Parganas & 78.07 & 3 & 84.95 & 3 \\
\hline Howrah & 77.01 & 4 & 83.85 & 4 \\
\hline Hooghly & 75.11 & 5 & 82.55 & 5 \\
\hline Darjeeling & 71.79 & 6 & 79.92 & 6 \\
\hline Paschim Medinipur & 70.41 & 7 & 79.04 & 7 \\
\hline South 24 Parganas & 69.45 & 9 & 78.57 & 8 \\
\hline Burdwan & 70.18 & 8 & 77.15 & 9 \\
\hline Nadia & 66.14 & 11 & 75.58 & 10 \\
\hline Cooch Behar & 66.30 & 10 & 75.49 & 11 \\
\hline Dakshin Dinajpur & 63.59 & 12 & 73.86 & 13 \\
\hline Jalpaiguri & 62.85 & 13 & 73.79 & 14 \\
\hline Bankura & 63.44 & 15 & 70.95 & 15 \\
\hline Birbhum & 61.48 & 17 & 70.90 & 16 \\
\hline Murshidabad & 54.35 & 16 & 67.53 & 17 \\
\hline Purulia & 55.57 & 18 & 65.38 & 18 \\
\hline Maldah & 50.28 & 19 & 62.71 & 19 \\
\hline Uttar Dinajpur & 47.89 & & 60.13 & 77.08 \\
\hline West Bengal & 68.64 & & \\
\hline
\end{tabular}


Table 2: Female literacy rate of Murshidabad district

\begin{tabular}{|c|c|c|c|c|c|c|}
\hline \multirow{2}{*}{ S1. No. } & \multirow{2}{*}{ Block Name } & $\mathbf{2 0 0 1}$ & & $\mathbf{2 0 0 1 1}$ & & Female \\
& & Block Name & $\begin{array}{c}\text { Female } \\
\text { Literacy (\%) }\end{array}$ & & Block Name & $\begin{array}{c}\text { Female Literacy Change } \\
\text { from 2001 to 2011 (\%) }\end{array}$ \\
\hline 1 & Behrampore & 57.50 & Behrampore & 70.34 & Samserganj & 19.57 \\
\hline 2 & Hariharpara & 52.30 & Hariharpara & 68.39 & Murshidabad Jiaganj & 17.50 \\
\hline 3 & Jalangi & 50.90 & Beldanga I & 68.08 & Suti I & 17.48 \\
\hline 4 & Nowda & 50.40 & Raninagar I & 66.03 & Suti II & 17.48 \\
\hline 5 & Beldanga I & 50.10 & Bhagwangola I & 65.89 & Jalangi & 17.18 \\
\hline 6 & Burwan & 49.20 & Nowda & 65.24 & Raghunathganj II & 17.16 \\
\hline 7 & Raninagar I & 49.10 & Jalangi & 65.24 & Beldanga II & 16.85 \\
\hline 8 & Nabagram & 48.90 & Murshidabad Jiaganj & 65.16 & Lalgola & 16.80 \\
\hline 9 & Domkal & 48.20 & Nabagram & 64.98 & Domkal & 16.78 \\
\hline 10 & Murshidabad Jiaganj & 46.90 & Beldanga II & 64.40 & Raninagar II & 16.76 \\
\hline 11 & Bharatpur II & 46.80 & Domkal & 63.31 & Sagardighi & 16.56 \\
\hline 12 & Bhagwangola I & 46.70 & Bhagwangola II & 63.06 & Khargram & 16.54 \\
\hline 13 & Sagardighi & 46.20 & Lalgola & 62.76 & Bharatpur II & 16.51 \\
\hline 14 & Lalgola & 45.80 & Burwan & 62.60 & Bhagwangola II & 16.47 \\
\hline 15 & Raninagar II & 45.60 & Raninagar II & 62.36 & Bhagwangola I & 16.36 \\
\hline 16 & Beldanga II & 45.20 & Sagardighi & 62.05 & Farakka & 16.27 \\
\hline 17 & Bhagwangola II & 44.50 & Bharatpur II & 60.97 & Nabagram & 16.26 \\
\hline 18 & Khargram & 43.20 & Raghunathganj I & 59.74 & Raninagar I & 16.14 \\
\hline 19 & Bharatpur I & 42.90 & Kandi & 58.25 & Hariharpara & 16.09 \\
\hline 20 & Kandi & 42.20 & Bharatpur I & 57.57 & Burwan & 16.04 \\
\hline 21 & Raghunathganj I & 42.00 & Raghunathganj II & 57.45 & Beldanga I & 15.79 \\
\hline 22 & Raghunathganj II & 40.00 & Khargram & 57.16 & Nowda & 15.63 \\
\hline 23 & Farakka & 37.50 & Farakka & 53.77 & Raghunathganj I & 15.45 \\
\hline 24 & Suti I & 35.60 & Suti I & 53.08 & Kandi & 15.37 \\
\hline 25 & Suti II & 32.50 & Suti II & 49.98 & Bharatpur I & 15.35 \\
\hline 26 & Samserganj & 30.00 & Samserganj & 49.57 & Behrampore & 12.84 \\
\hline Murshidabad district & 47.63 & & 63.88 & & 16.25 \\
\hline
\end{tabular}

Source: District Statistical Handbook, 2010-2011, Murshidabad district

Table 3: Block wise male- female disparity of literacy in Murshidabad district

\begin{tabular}{|c|c|c|c|c|c|c|}
\hline \multirow{2}{*}{ Sl. No. } & \multirow{2}{*}{ Bloc Name } & \multicolumn{3}{|c|}{2011 Literacy (\%) } & \multirow{2}{*}{ Male-Female Disparity Index } & \multirow{2}{*}{ Rank } \\
\hline & & Male & Female & Total & & \\
\hline 1 & Bhagwangola II & 62.58 & 63.06 & 62.82 & 0.039 & 1 \\
\hline 2 & Domkal & 64.47 & 63.31 & 63.90 & 0.052 & 2 \\
\hline 3 & Nowda & 66.91 & 65.24 & 66.09 & 0.058 & 3 \\
\hline 4 & Bhagwangola I & 67.64 & 65.89 & 66.79 & 0.059 & 4 \\
\hline 5 & Hariharpara & 69.97 & 68.39 & 69.20 & 0.060 & 5 \\
\hline 6 & Raninagar II & 64.78 & 62.36 & 63.60 & 0.061 & 6 \\
\hline 7 & Raninagar I & 68.42 & 66.03 & 67.25 & 0.064 & 7 \\
\hline 8 & Lalgola & 65.81 & 62.76 & 64.32 & 0.067 & 8 \\
\hline 9 & Jalangi & 69.36 & 65.24 & 67.35 & 0.077 & 9 \\
\hline 10 & Beldanga I & 71.92 & 68.08 & 70.06 & 0.077 & 10 \\
\hline 11 & Sagardighi & 68.34 & 62.05 & 65.26 & 0.092 & 11 \\
\hline 12 & Beldanga II & 71.10 & 64.40 & 67.86 & 0.097 & 12 \\
\hline 13 & Raghunathganj II & 64.71 & 57.45 & 61.17 & 0.098 & 13 \\
\hline 14 & Behrampore & 76.52 & 70.34 & 73.51 & 0.099 & 14 \\
\hline 15 & Murshidabad Jiaganj & 72.82 & 65.16 & 69.12 & 0.105 & 15 \\
\hline 16 & Raghunathganj I & 68.99 & 59.74 & 64.49 & 0.114 & 16 \\
\hline 17 & Suti I & 62.84 & 53.08 & 58.06 & 0.118 & 17 \\
\hline 18 & Bharatpur II & 70.96 & 60.97 & 66.07 & 0.121 & 18 \\
\hline 19 & Bharatpur I & 67.94 & 57.57 & 62.93 & 0.123 & 19 \\
\hline 20 & Suti II & 60.44 & 49.98 & 55.23 & 0.125 & 20 \\
\hline 21 & Samserganj & 60.42 & 49.57 & 54.98 & 0.129 & 21 \\
\hline 22 & Farakka & 65.56 & 53.77 & 59.75 & 0.134 & 22 \\
\hline 23 & Nabagram & 76.44 & 64.98 & 70.83 & 0.136 & 23 \\
\hline 24 & Khargram & 69.69 & 57.16 & 63.56 & 0.140 & 24 \\
\hline 25 & Burwan & 74.97 & 62.60 & 68.96 & 0.141 & 25 \\
\hline 26 & Kandi & 71.66 & 58.25 & 65.13 & 0.147 & 26 \\
\hline \multicolumn{2}{|c|}{ Murshidabad district } & 71.02 & 63.88 & 67.53 & \multicolumn{2}{|l|}{0.100} \\
\hline
\end{tabular}

Source: District Statistical Handbook, 2014, Murshidabad district 


\subsection{Block wise female literacy in Murshidabad district- 2001}

Figure 3 and Table 2 represent the block-wise female literacy rate of the Murshidabad district in 2001. The highest female literacy found in Behrampore block (57.5\%) and lowest in Samserganj block (only 30\%). The district has been divided into five zones such as very high (52.31$57.5 \%)$, high $(46.91 \%-52.30 \%)$, moderate $(43.21 \%$ $46.90 \%)$, low (37.51-43.2\%) and very low (30-37.5\%) female literacy rate. Only one block falls into the very high female literacy zone, which was the Berhampore block, located in the middle part of the district. The southeastern part of the district is mainly high female literacy zone, includes 8 blocks such as Hariharpara (52.3\%), Jalangi
$(50.9 \%)$, Nowda $(50.4 \%)$, Beldanga I $(50.1 \%)$, Burwan (49.2\%), Raninagar I (49.1\%), Nabagram (48.9\%) and Domkal $(48.2 \%)$. The moderate female literacy rate is mainly in the middle east part of the district, includes 8 blocks - Murshidabad Jiaganj (46.9\%), Bharatpur II (46.8\%), Bhagwangola I (46.7\%), Sagardighi (46.2\%), Lalgola (45.8\%), Raninagar II (45.6\%), Beldanga II (45.2\%) and Bhagwangola II (44.5\%). 5 blocks fall in low female literacy rate; these are Khargram (43.2\%), Bharatpur I (42.9\%), Kandi (42.2\%), Raghunathpur I (42\%) and Raghunathpur II (40\%). 4 blocks are under the very low female literacy rate zone, which is located in the northern part of the district, such as Farakka (37.5\%), Suti I (35.6\%), Suti II $(32.5 \%)$ and Samserganj block (30\%).

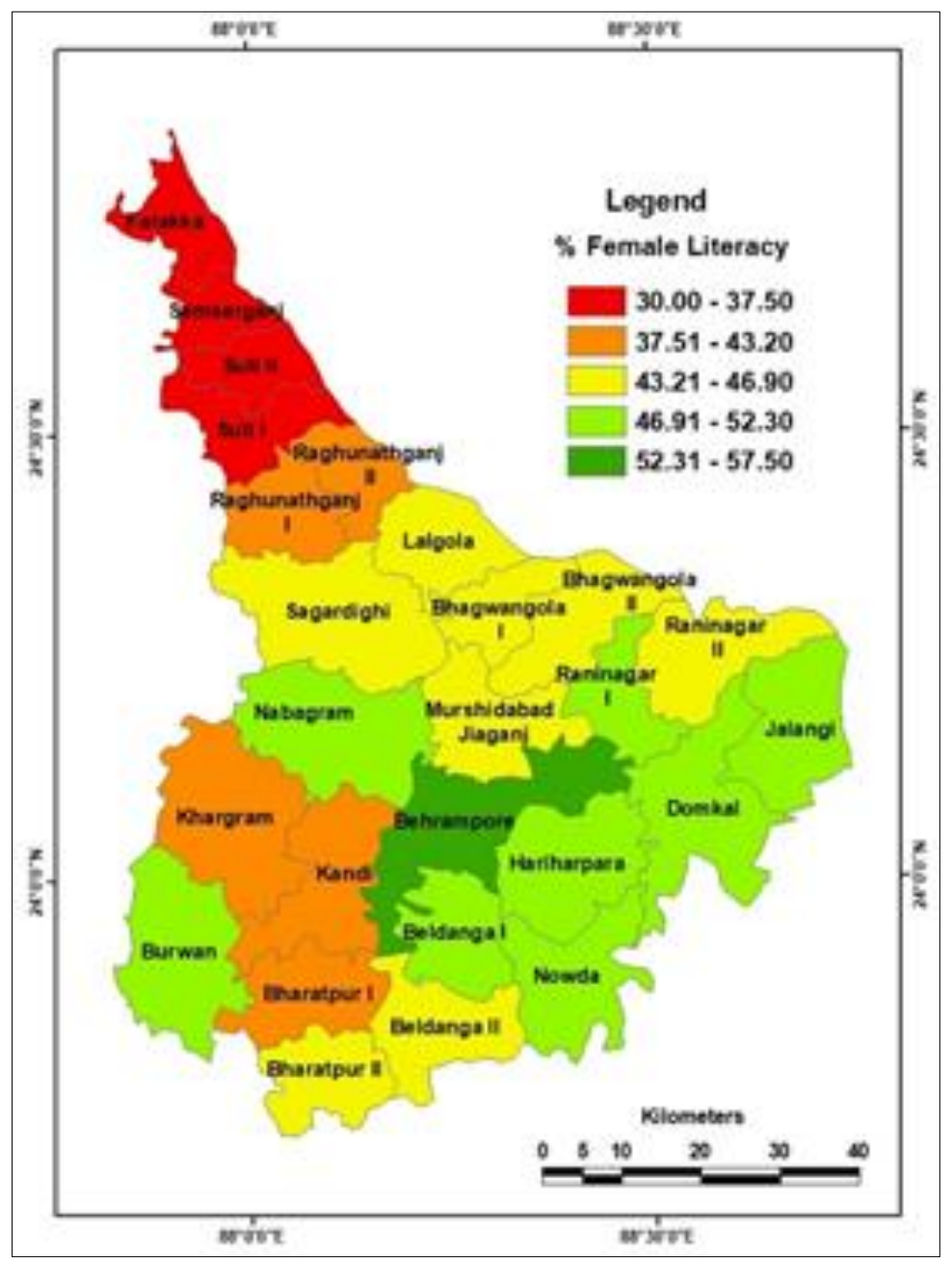

Fig 3: Block wise female literacy rate in Murshidabad district - 2001.

\subsection{Block wise female literacy in Murshidabad district - 2011}

Figure 4 and Table 2 represent the block-wise female literacy rate of Murshidabad district in the Census year 2011, which portrays the similar trend of literacy of the previous decade in Murshidabad district. The highest female literacy found in Behrampore block (70.34\%) and lowest in Samserganj block (only 49.57\%). Here also the district is divided into 5 zones, such as very high $(66.04 \%-70.34 \%)$, high $(63.32 \%-66.03 \%)$, moderate $(59.75 \%-63.31 \%)$, low $(53.78-59.74 \%)$ and very low $(49.57 \%-53.77 \%)$ female literacy zone. 3 blocks, which located in the middle part of the district, show the very high female literacy rate; these blocks are Behrampore (70.34\%), Hariharpara (68.39\%) and
Beldanga I block (68.08\%). 7 blocks are under the high female literacy zone such as Raninagar I (66.03\%), Bhagwangola I $(65.89 \%)$, Nowda $(65.24 \%)$, Jalangi (65.24\%), Murshidabad Jiaganj (65.16\%), Nabagram $(64.98 \%)$ and Beldanga II (64.4\%). Moderate female literacy is seen in Domkal $((63.31 \%)$, Bhagwangola II ((63.06\%), Lalgola (62.76\%), Burwan $(62.6 \%)$, Raninagar II $(62.36 \%)$, Sagardighi $(62.05 \%)$ and Bharatpur I (60.97\%). The low female literacy rate is mainly marked in 5 blocksRaghunathganj I (59.74\%), Kandi (58.25\%), Bharatpur I (57.57\%), Raghunathganj II $(57.45 \%)$ and Khargram $(57.16 \%)$. The northern part of the district is under the very low female literacy area, and there are 4 blocks such as 
Farakka (53.77\%), Suti I (53.08\%), Suti II (49.98\%) and Samerganj (49.57\%).

Table 2 also presents the block-wise female literacy change from 2001 to 2011 . It is noticed that the female literacy rate is significantly increased in each block of the Murshidabad district. Maximum female literacy increased is found in Samserganj block $(19.57 \%)$ and minimum in Behrampore block (12.84\%) from 2001 to $2011.16 \%$ to $18 \%$ female literacy increased are identified in Murshidabad Jiaganj (17.5\%), Suti I (17.48\%), Suti II (17.48\%), Jalangi
(17.18\%), Raghunathpur block (17.165\%), Beldanga II (16.85\%), Lalgola (16.8\%), Domkal (16.78\%), Raninagar II (16.76), Sagardighi (16.56\%), Khargram (16.54\%), Bharatput II (16.51\%), Bhagwangola II (16.47\%), Bhagwangola I (16.36\%), Farakka (16.57\%), Nabagram $(16.26 \%)$, Raninagar I (16.14\%) and Hariharpara block (16.09\%). $12 \%$ to below $16 \%$ female literacy changed are noticed in Beldanga I (15.79\%), Nowda (15.63\%), Raghunathganj I (15.46\%), Kandi (15.37\%), Bharatpur I $(15.35 \%)$ and Berhampore (12.84\%).

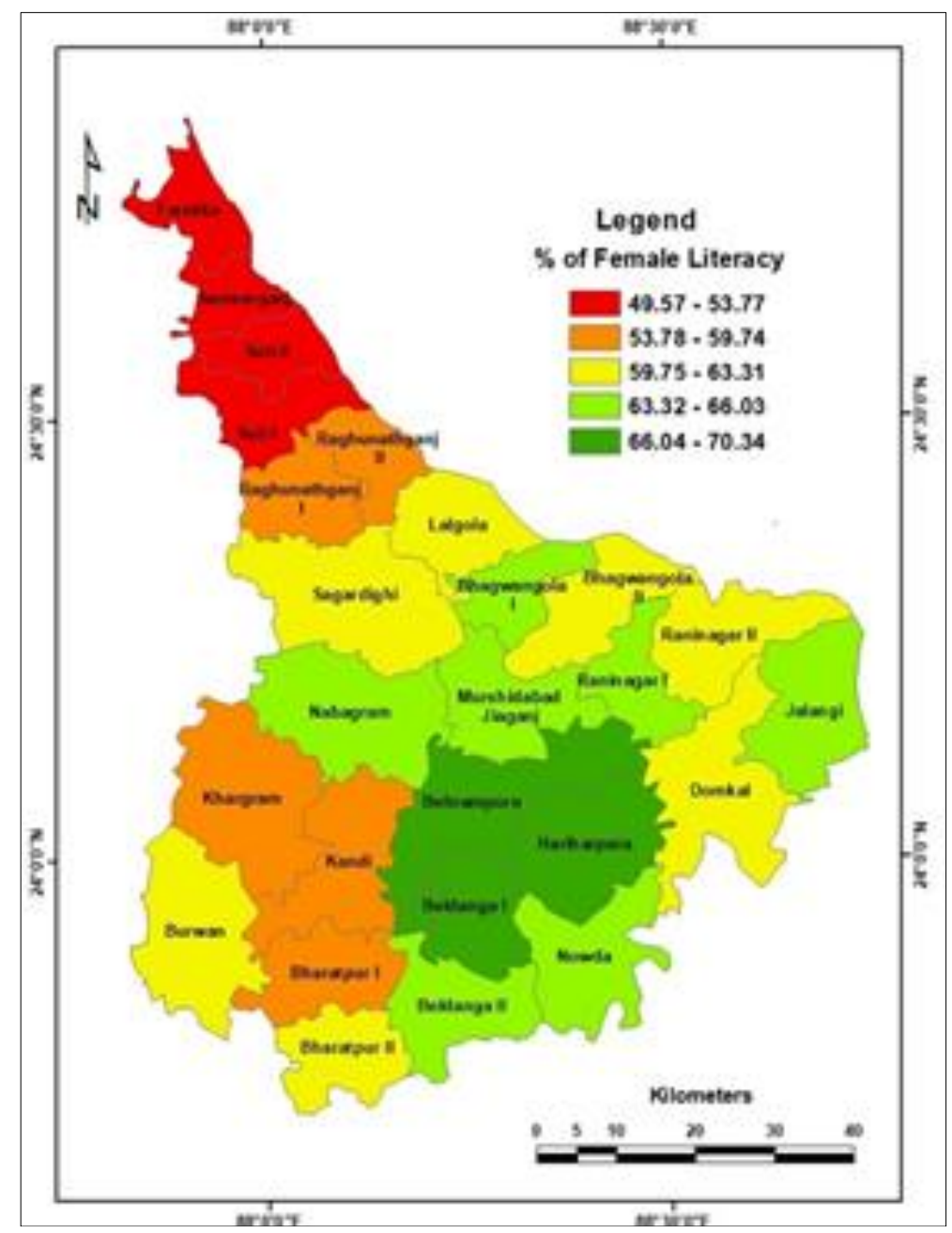

Fig 4: Block wise female literacy rate in Murshidabad district - 2011.

\subsection{Block wise female disparity in literacy of Murshidabad district - 2011}

The male-female disparity in education means gender inequality in education. The male-female disparity in literacy is calculated using the Census data of 2011 based on Sopher's Disparity Index formula. It measures the degree of gender disparity in education. Where the male-female disparity in literacy index is high, gender inequality will be high and if the index value is low, it reflects the opposite condition. Table 3 and Figure 5 delineate the block-wise male-female disparity of the Murshidabad district. Disparity in the literacy of the district was 0.100 . The lowest disparity is found in Bhagwangola II (0.039) and highest in Kandi block (.147). Figure 5 clearly remarks that the eastern part of the district, the disparity in literacy was very less. Still, almost the whole western part and northern part represented a high disparity in literacy. There are 14 blocks, in which male-female disparity are below district average, these block namely Bhagwangola II (0.039), Domkal (0.052), Nowda (0.058), Bhagwangola I (0.59), Hariharpara (0.060), Raninagar II (0.061), Raninagar I (0.064), Lalgola (0.067), Jalangi (0.077), Beldanga I (0.077), Sagardighi (0.092), Beldanga II (0.097), Raghunathganj II (0.098) and Berhampore block (0.099). While, the male-female disparity of the remaining 12 blocks is above the district average, these blocks are Murshidabad Jiaganj (0.105), Raghunathganj I (0.114), Suti I (.0118), Bharatpur II (.0121), Bharatpur I (0.123), Suti II (0.125), Samerganj (0.129), Farakka (0.134), Nabagram (0.136), Khargram (0.141), Burwan (0.141) and Kandi (0.147). One thing that has been particularly noticed that both the Census year 2001 and 2011, the female literacy rate is highest in Berhampore block but the male-female disparity is comparatively high (.099) and the block rank is 14 out of 26 blocks of the district. On the other hand, the female literacy rate is lowest in the both Census year in the Sumserganje block, but male- 
female disparity in this block comparatively low and the block rank is 21 out of 26 blocks in the Murshidabad

district.

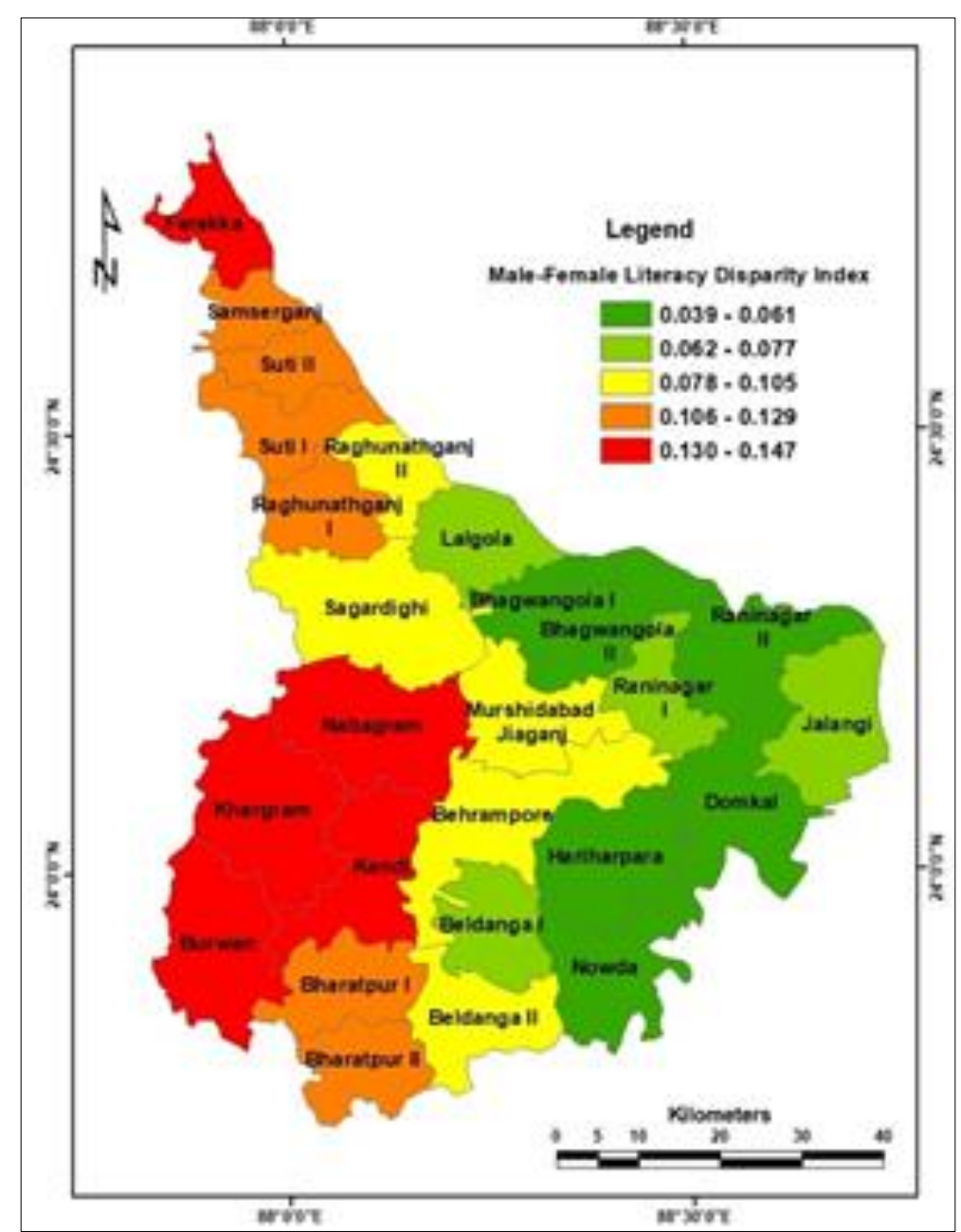

Fig 5: Block wise male female disparity in literacy of Murshidabad district - 2011

\section{Conclusion}

The study mainly emphasizes on analysis block-wise women's literacy and gender disparity in the literacy of Murshidabad district. It is clearly illustrated that the blocklevel female literacy rate is gradually increased. Especially in the last decade, changes have been taken place in the female literacy rate not only in the Murshidabad district but also in West Bengal. There exists a considerable regional variation in the block level female literacy in the Murshidabad block. A very high level of education was seen in the middle and eastern regions of the study area. At the same time, the whole of the western part was characterized by a medium level of education. In contrast, the very low level of female education was found in the northern region. The above pattern of the educational level of the Murshidabad district could be correlated with the prevailing economic activity. As the urban area is located in the middle Eastern part, most of the people are engaged in secondary and tertiary activities, and they give more weightage to education to get employment. In contrast, the northern and eastern part of the district has primary sectors activities, so they give less preference to education.

There is still gender disparity in education in this study area, especially in the western part of the district. Although female literacy was very low in the northern region, the male-female disparity in literacy was comparatively better than the part of the west. Like the high female literacy rate, the male-female disparity in literacy was much lower in the middle and eastern parts of the district. There may be few reasons for less gender inequality in education in the east and central region, one is an increase in awareness of female education and others may be better education facilities, better infrastructure and accessibility of communication. The key factor of this female literacy increases and reducing gender inequality in education may be various Government educational programs of the Central Government as well as the State Government for girls and other reasons may be changed in the superstitious mentality of society to female, socio-economic development, modernization, globalization and the Government law. However, men are far ahead of women in literacy and there is still gender disparity in our society not only in education but also in various aspects of society. In the case of literacy, this disparity has stepwise reduced. Hopefully, in the near future gender inequality will be eliminated and social equality will prevail. In this regard, the Government as well as every citizen must take equal responsibility so that women can express themselves and achieve social establishment by following their equal constitutional rights.

\section{Recommendations}

1. In-depth field survey work on women education and gender disparity should be done in the Murshidabad 
district to find out the main reasons for the backwardness of women in education.

2. The Government should introduce new schemes for the improvement of women's education and take appropriate measures to reduced school drop-out of girl's students.

3. Mass awareness should be enhanced to women's education.

4. Parents should look after their son and daughter equally and create a conducive environment for their learning.

5. The participation of women in school education, as well as higher education, should be ensured.

6. To eliminate regional disparity in literacy, proper educational infrastructure should be built in urban as well as village areas.

7. Adult education should be introduced so that aged women who are deprived of education also can get the light of knowledge.

\section{References}

1. Patil NA, Suryawanshi AS. Disparity in the Level of Literacy a Spatio-Temporal Case Study of Jalgaon District Maharashtra State (2001-2011). Journal of Emerging Technologies and Innovative Research (JETIR) 2019, 6(3).

2. Barman B, Chouhan P. Spatio-temporal Variation in Literacy among the Scheduled Caste Population: A Sub-divisional Scenario of Koch Bihar District, West Bengal, India. IOSR Journal of Humanities and Social Science (IOSR-JHSS) 2017;22(7):01-11.

3. Biswas S. Educational Status of Women in West Bengal. JETIR 2017, 4(11).

4. Chakraborty P. Educational Status of the Tribal West Bengal: Special References to the Paschim Medinipur District. Global Journal of Sociology and Anthropology 2019;9:1-14.

5. Ghosh I. Educational Status of Scheduled Caste Women in Four Eastern States of India. International Journal of Research in Social Sciences 2019, 9(6).

6. Gouri V. Women Education and Empowerment in India with Reference to Telangana and Andhra Pradesh. Journal of Community Guidance \& Research 2017;34(2):394-414.

7. Hussain N. Muslims of West Bengal: An Analysis of the Educational Status of a Minority Community in India. Journal of Muslim Minority Affairs 2009, 29(2).

8. Hussain N, Abbas Z, Owais S. Muslims in West Bengal: Trend of Population Growth and Educational Status. Islam and Muslim Societies: A Social Science Journal. 2012, 5(1).

9. Manjunatha NK, Hurakadli SM. A Discourse on Gender Disparity: A Study on Taluks of Belagavi District. International Journal of Trend in Scientific Research and Development (IJTSRD) 2017, 1(5).

10. Kumar N, Kumar N, Rani R. Gender Disparity in Literacy: Districts Level Evidence from Selected States of India. Educational Quest: An Int. J. of Education and Applied Social Sciences 2016, 7(3).

11. Seker M, Alagarsamy S. Women Empowerment: Role of Education. IJMSS 2014, 2(12).

12. Maji K, Sarkar S. Gender Disparity in Literacy Level among Scheduled and Non-scheduled Population: A Case Study of Bankura District, West Bengal (India).
International journal of basic and applied research 2018, 8.

13. Mulimani AA, Pujar LM. Spatial Disparity of RuralUrban Literacy in Haveri District. International Multidisciplinary Research Journal 2015, 3(6).

14. Mundhe NN, Pawar DB, Rokade PD. Use of Disparity Index for Identifying Rural - Urban Literacy Pattern of Pune District, Maharashtra. IMPACT: International Journal of Research in Humanities, Arts and Literature (IMPACT: IJRHAL) 2017;5(8):61-70.

15. Margaret P. Women Education in India. International Journal of Development Research 2017;07(12):1784617848 .

16. Rahaman M, Rahaman H. Gender Disparity in Literacy in Malda District. International Journal of Research in Social Sciences 2018, 8(10).

17. Roy D, Mondal A. Rural Urban Disparity of Literacy in Murshidabad District, WB, India. International Research Journal of Social Sciences 2015;4(7):19-23.

18. Rukhsana, Alam A. Literacy Differentials among Scheduled Caste and Non-Schedule Castes in West Bengal, India: A District Wise Study. International Journal of Innovative Research in Science, Engineering and Technology 2014, 3(3).

19. Saravanakumar S, Palanisamy M. Status of Primary Education of Scheduled Caste Children. International Journal of Research in Humanities and Social Sciences. 2013, 1(8).

20. Saxena K. Status of Women Education in India with Particular Reference to Women Empowerment and Development. IOSR Journal of Humanities and Social Science (IOSR-JHSS) 2017;22(3):01-04.

21. Sopher ED. A Measure of Disparity. The Professional Geographer 1974. 